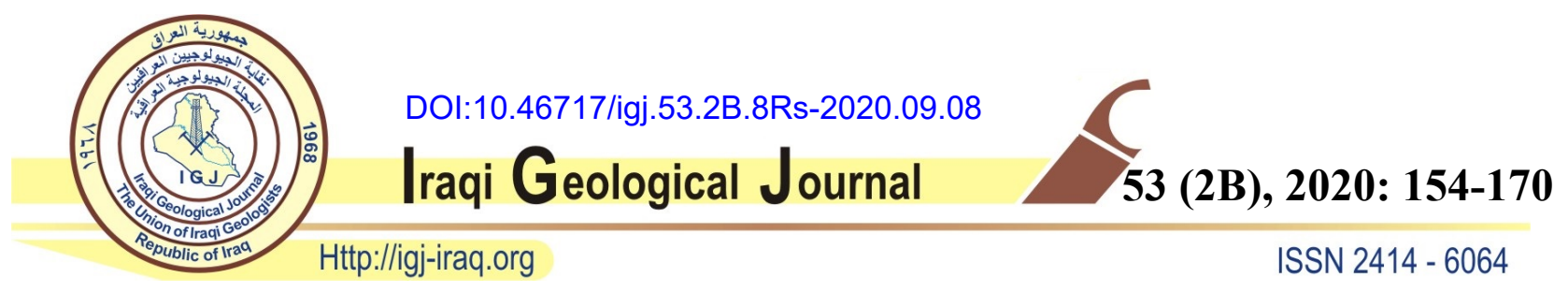

\title{
HYPSOMETRIC ANALYSIS OF AL-ADHAIM BASIN USING A NEW GIS- TECHNIQUE
}

\author{
${ }^{1}$ Ahmed H. Al-Sulttani" and ${ }^{2}$ Ayad A. Beg \\ ${ }^{1}$ Department of Environmental Planning, Faculty of Physical Planning, University of Kufa, Najaf, Iraq \\ ${ }^{2}$ Department of Geography, College of Education, Mustansiriyah University, Baghdad, Iraq \\ Email: ahmedh.alsulttani@,uokufa.edu.iq \\ Received: 25 May 2020; accepted: 27 June 2020
}

\begin{abstract}
Al-Adhaim dam basin is extended across the boundaries of Salahuddin, Kirkuk, and Sulaymaniyah provinces in the northern part of Iraq, covering an area of $11831 \mathbf{k m}^{2}$. The area is covered mainly in most upperparts by sedimentary rocks of the lower Eocene to Pliocene ages. The lower parts are occupied by sheet runoff deposits from the Quaternary age. The objectives of the current study are to carry out detailed measurements of hypsometric parameters to evaluate the degree of erosion conditions and to show the essential factors controlling the development of geomorphic stages in different parts of the basin. The analysis was carried out based on ASTER GDEM data using ArcGIS v10.6 hydrology toolbox and the morphometric toolbox and dividing the basin into fifteen sub-basins. The results show that the Al-Adhaim basin passes in the monadnock phase with a hypsometric integral of $19.02 \%$ and a highly concaved hypsometric curve. The sub-basins are classified into two groups of geomorphic stages, i.e., mature stage and Monadnock stage with hypsometric integral values between $18.4 \%$ and $34.6 \%$. The results reveal the basin was controlled mainly by slopes, lineaments, Tertiary outcrops, Quaternary deposits, and hydrological soil groups $B$ and D.
\end{abstract}

Keywords: Hypsometry; GIS applications; Morphometric toolbox; DEM; Al-Adhaim Dam

\section{INTRODUCTION}

The hypsometric analysis is a quantitative study of the drainage basin, and it reflects the geomorphic cycle and the manner of mass distribution in the basin. To understand the evolution and development of a landscape, the controlling factors such as weathering, deposition, erosion, and tectonic processes added to the fact that the lithology and hydrological behavior analysis are 
required (Ahmed and Rao, 2016). Many methods and techniques have been used in computing the hypsometric parameters, and their accuracy depends on the analysis technique, source, and used data scale. The restriction of hypsometric measurement in the past due to the intensive computation requirement and limitation of measurement tools at that time and still, the hypsometric computation has been witnessed more interest with the use of planimeter as a more efficient tool for area measurement and visual assessment of the contours, while the advances in GIS techniques, make the hypsometric analysis worth more attention as a means for quantitative analysis of catchments (Dowling et al., 1998).

There are various studies were conducted to evaluate geomorphic stages, erosional conditions, and mass development of drainage basins. The importance of hypsometric analysis for the large basins is to study the overall slope of selected drainage basins (Langbein, 1947). The hypsometric properties are used to study small-scale basins of low order to evaluate the geomorphic cycle and determine the mass distribution within the basin from base to top (Miller, 1953; Schumm, 1956 and Strahler, 1952b). Hypsometric analysis of drainage basin is based on the hypsometric curve (HC) as a graphical representation of relative area situated above various altitudes on the abscissa, and relative altitude on the ordinate and hypsometric Integral (HI) calculated from the ratio of the area below $\mathrm{HC}$ to that of the rectangle delimited by the maximum values on the abscissa and ordinate (Strahler, 1952b; Strahler, 1957 and Zavoianu, 1985). The change in the shape of HC and values of $\mathrm{HI}$ is related to erosion processes, lithology, and structure (Moglen and Bras, 1995 and Willgoose and Hancock, 1998). The HI has been widely used in the interpretation of the stages of watersheds according to equilibrium and non-equilibrium phases of landscape because of uplift and denudation processes, and providing a measure of landmass volume distribution remaining beneath or above a basal reference plane (Ohmori, 1993; Singh et al., 2008; Strahler, 1952a; Vivoni et al., 2008 and Willgoose and Hancock, 1998). According to the HI values and HCs, the geomorphic cycle of erosion and the watershed are divided into three stages; Monadnock stage (HI $\leq 35 \%$ ) refers to a phase represents isolated and erosion-resistant hills and mountains that rise above the general erosion level, which is called a peneplain (Vanderwaal and Ssegane, 2013), equilibrium, Mature stage $(35 \% \leq \mathrm{HI} \leq 60 \%)$ and non-equilibrium, Youth stage $(\mathrm{HI} \geq 60 \%)$ mean the watershed is highly susceptible to more erosion (Strahler, 1952b).

The shape of $\mathrm{HC}$ changes from concave-convex to concave as the basin reaches the equilibrium mature stage (Soares and Riffel, 2006). HC and HI are strongly related to the erosional processes, 
curvature, and morphology of landform (Cohen et al., 2008). HC is associated with i) the volume of the rock and soil mass and ii) the volume of eroded mass in a basin compared to the remaining mass (Hurtrez et al., 1999 and Singh et al., 2008). Khatun and Pal (2016) referred to the direct impact of basin topography on the shape of the hypsometric curve.

Although the effect of slopes on basin attributes, HC may be strongly influenced by the diverse geometry of the drainage network (Willgoose and Hancock, 1998). The runoff components are a function of the basin hypsometric form. The runoff amounts depend on the types of hydrologic soil groups described as group A, have low runoff and consist of mainly $90 \%$ gravel and $10 \%$ of clay, group B, when under wet conditions have a moderately low runoff, consist of $50-90 \%$ of gravel, sand and the remaining from clay and silt or loam, group $\mathrm{C}$, have moderately high runoff under wet conditions, consist of $20-40 \%$ of clay materials and less than $50 \%$ of sand, loam, and silt, and group D, water movement through such soil is restricted and make the soil have high runoff during wet conditions, consists of more than $40 \%$ of clay with less than $50 \%$ of sand and loam or silt materials (USGS, 2016). The use of SRTM data is essential in extracting the geomorphic features, terrain character, and analysis of hypsometric properties (Patel and Sarkar, 2010 and Sreedevi et al., 2009).

The current study aims to achieve the hypsometric analysis of Al-Adhaim dam sub-basins, using ASTER GDEM data, measuring the hypsometric parameters using the morphometric toolbox and analysis of the essential factors impact on development of the sub-basin's geomorphic stages, including geology, structure, drainage density, soil types, and slopes.

\section{STUDY AREA}

The Al-Adhaim dam's basin extended over three Iraqi governorates i.e., Salahuddin, Kirkuk, and Sulaymaniyah provinces cover an area of $11831.15 \mathrm{~km}^{2}$. Geographically the basin is bounded by latitudes from $34^{\circ} 30^{\prime}$ to $35^{\circ} 43^{\prime} \mathrm{N}$ and longitudes from $43^{\circ} 45^{\prime}$ to $45^{\circ} 25^{\prime} \mathrm{E}$ (Fig. 1). The basin is entirely located within Iraqi land and represents a watershed for two rivers: Tuz Chi and Tauk Chi the main branches of Al-Adhaim River. Al-Adhaim meets the Tigris River south of Balad city region. The total annual precipitation in the study area is about $200 \mathrm{~mm}$, and the mean annual temperature of about $28{ }^{\circ} \mathrm{C}$. Al-Adhaim flow system can be classified as an irregular flow system that is controlled by precipitation and in the summer the river turns dry (Abbas et al., 2018). 


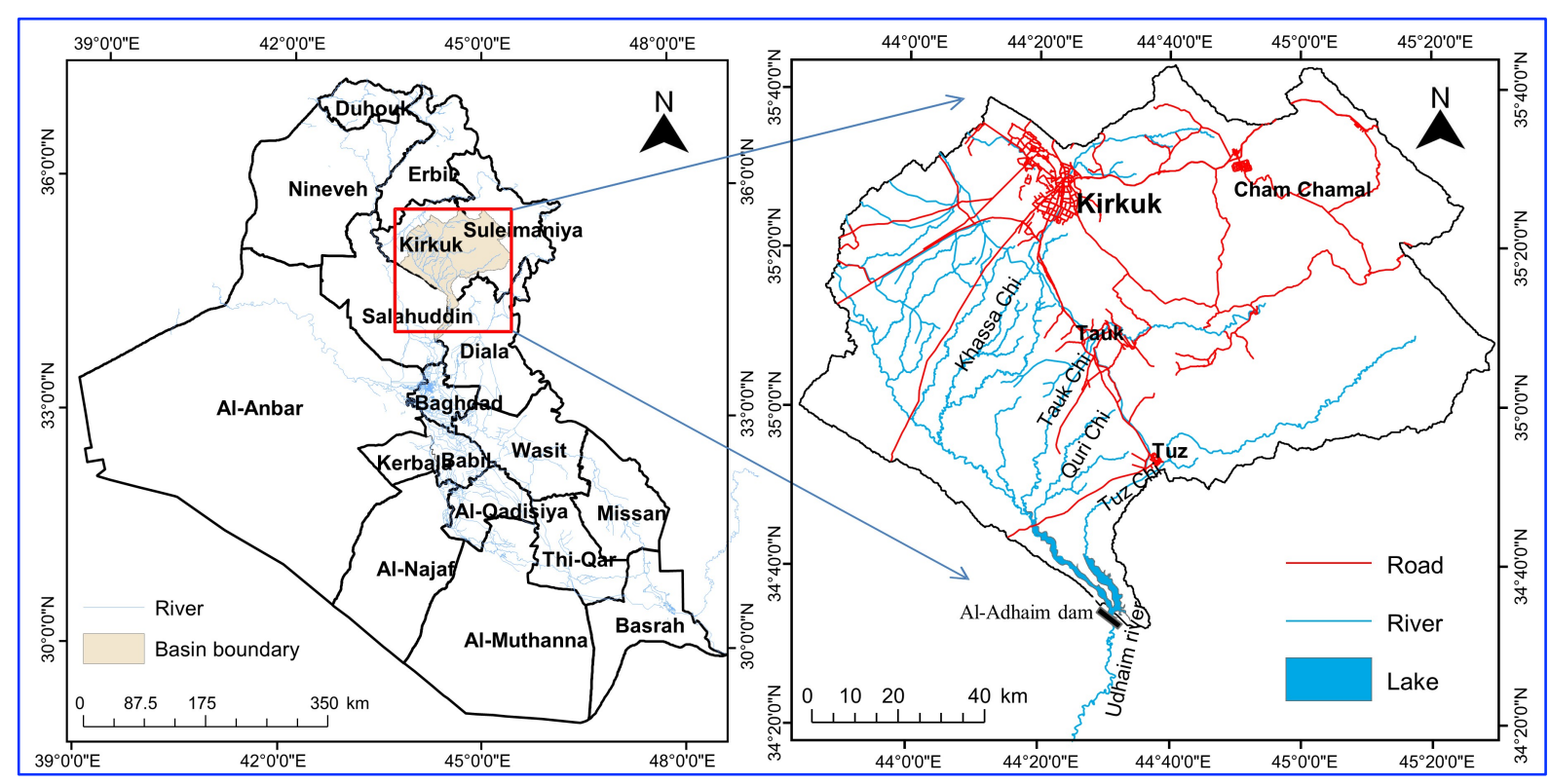

Fig. 1. Location map of Al-Adhaim dam basin

\section{GEOLOGIC AND STRUCTURAL SETTING}

Geological formations are clipped from the geologic map (Sissakian, 1993). Geologic setting of the basin shows Tertiary formations mostly cover the eastern parts, Pila Spi and Gercus formations mainly consist of well-bedded bituminous chalky, crystalline limestone, mudstones, sandstones, sandy marls, and lenticels of gypsum are found towards the top of the upper Paleocene and lower Eocene ages (Fig. 2a). Fatha Formation is extended as narrow belts along the fault cliffs in the middle parts. It is comprised of anhydrite, gypsum, and salt interbedded with limestone and marl of middle Miocene age. Injana Formation consists of red to grey color silty marlstone or claystone, siltstones, and medium to coarse-grained sandstone of upper Miocene. Bai Hassan and mukdadia formations consist of pebbly sandstones, siltstone, claystone, and conglomerate of most upper Miocene-Pliocene ages (Buday, 1980; Rashid et al., 2016 and Sissakian, 1993). Quaternary deposits are mainly covered the western parts of the basin, predominately of sheet runoff deposits, gypsiferous soil and silty clayey sand (Al-Kubaisi et al., 2018; Jassim and Goff, 2006 and Sissakian, 1993). Several folds and lineaments are extended through the study area with a major axis in NW-SE direction, with recognized faults along the major tributaries of Al-Adhaim river (Buday and Jassim, 1987 and Marouf and Al-Kubaisi, 2005) (Fig. 2b). Dense joints are dominant in the eastern part of the basin, making the rocks more prone to erosion processes. 


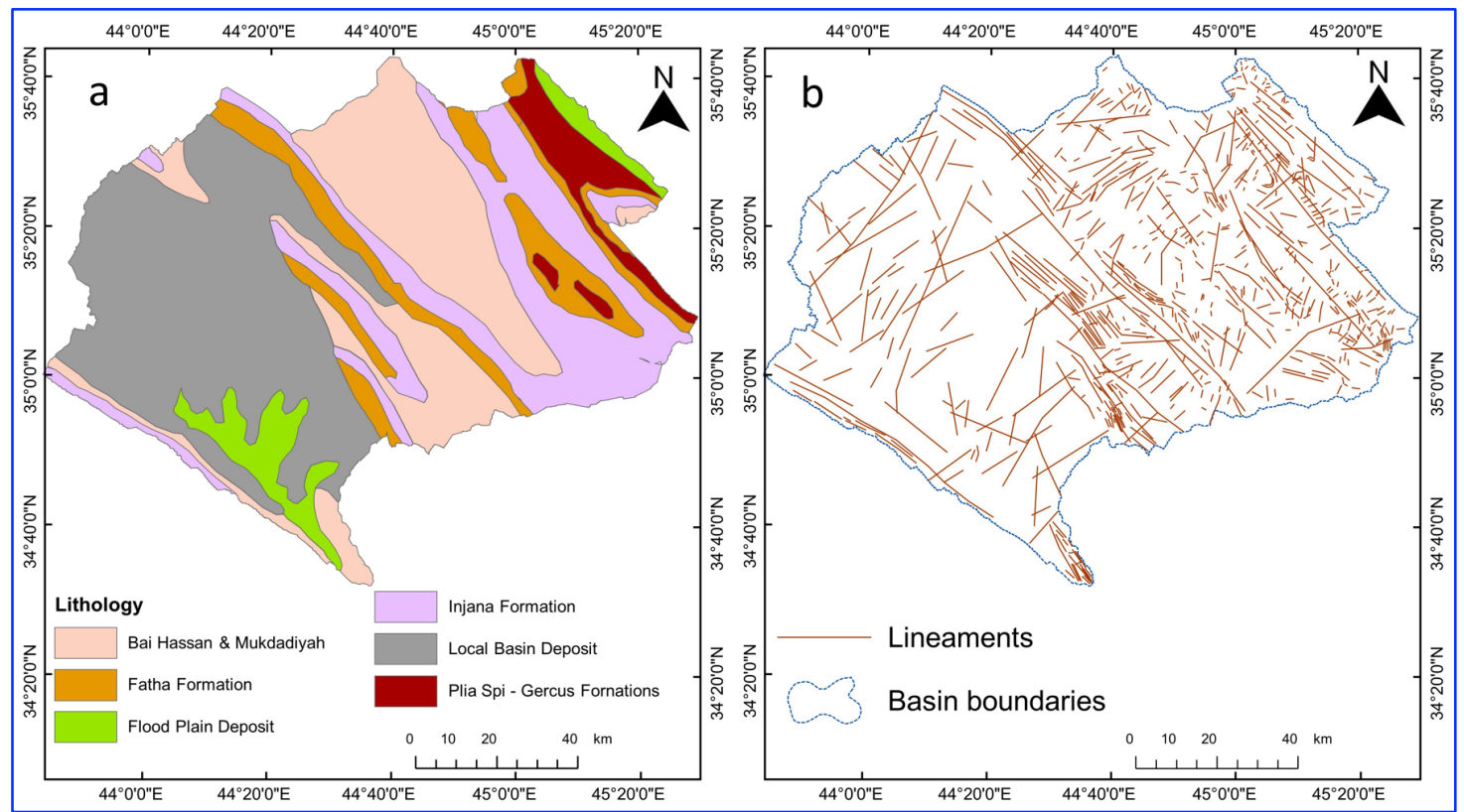

Fig. 2. a. Geological map (after Sissakian, 1993) b. Lineaments map

\section{METHODOLOGY}

To evaluate the geomorphic development, erosion processes in Al-Adhaim dam basin and its relations with calculated HI, many factors have been used for comparison which are (lineaments, geological formations and soils deposits HC, HI, DEM, Slopes, drainage network, basin and subbasins are extracted and calculated from the Global Digital Elevation Model (ASTER GDEM) data. Lineaments have been extracted from Landsat 8 (USGS, 2016) using PCI-Geomatica.

\section{Soil Types}

The area is covered by various soil types ranged from deep to shallow phases, a reddish-brown soil of deep phase, badland, gullied land, lithosolic soil overlay the sandstones, gypsum, limestone rocks and brown soil of medium to shallow phase (Buringh, 1960 and Muhaimeed et al., 2014) (Fig. 3a). Most of the soil types are developed in fluvial deposits and mixed weathering products of sandstones and gypsum rocks. The steeply sloped area is characterized by the presence of rough broken and stony land.

\section{Topography}

The topography of the area ranges in the elevations from 94 to 1840 meters above sea level. Gentle slopes are dominant in the western parts of the basin, whereas steep slopes characterize the eastern parts ranged from flat to very steep along the ridges area (Fig. 3b). 


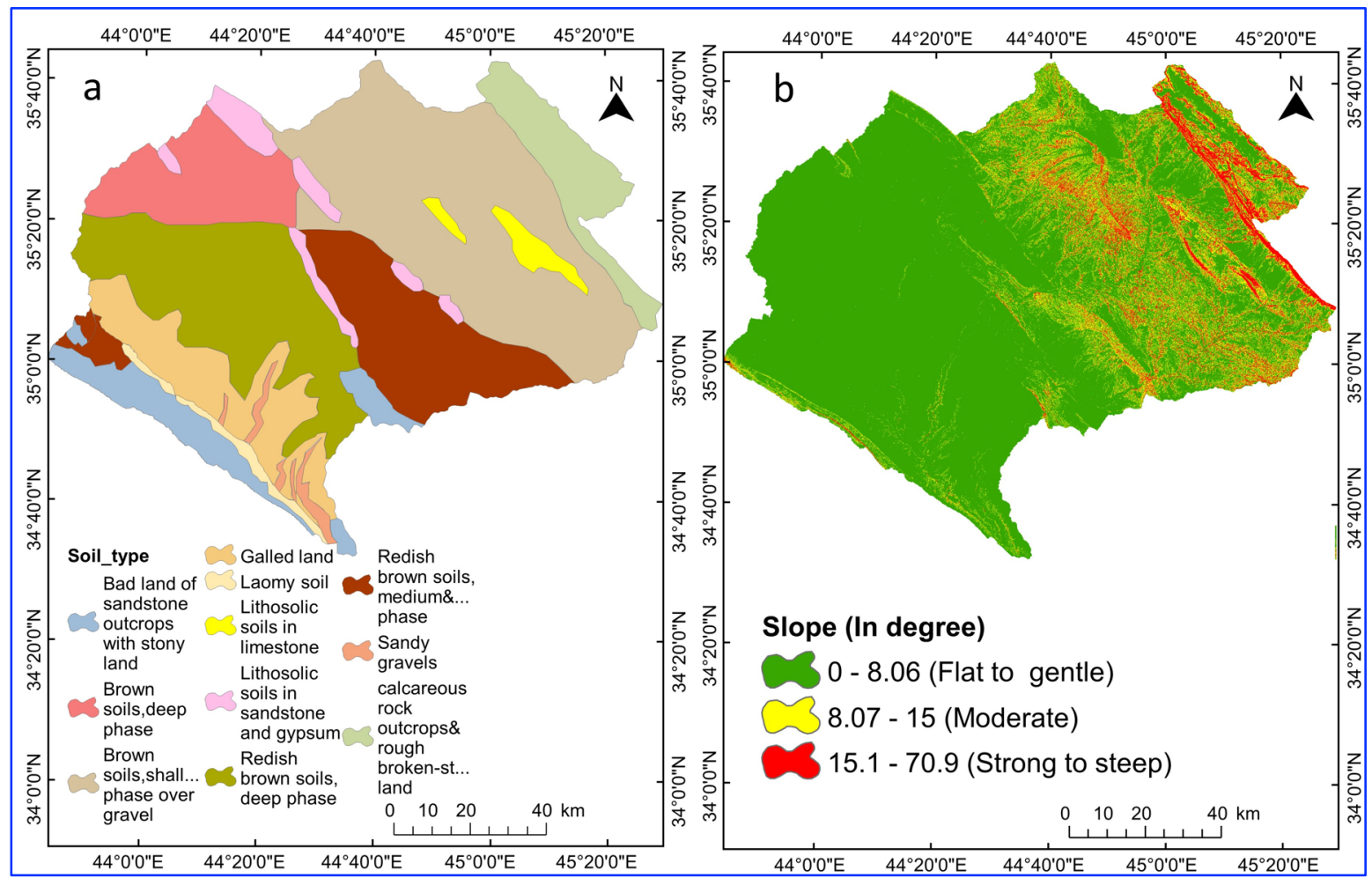

Fig. 3. a. Soil map, after (Buringh, 1960 and Muhaimeed et al., 2014) b. Slopes map

\section{GIS Technique and Analysis of Basin Hypsometry}

\section{Hypsometric calculation method}

Although many tools and software are developed to do hypsometric analysis, the GIS software still has several drawbacks. One of the first extensions for hypsometric analysis execute with ArcView GIS and published on the ESRI website (Beg, 2008). For ArcGIS, hypsometry toolbox working under ArcGIS v.9.3 has been published which is required preparation of many layers, find main channel path flow, area gradient, stream gradient, maximum elevation and maximum flow length (Davis, 2010). The open software module was automated in System for Automated Geo-scientific Analyses (SAGA) has some limitations and problems (Sivakumar et al., 2011). Another tool for ArcGIS using Python language to calculate the topographic parameters, including area- elevation ratios have a drawback as well because it is required to draw HC (Gökgöz et al., 2016).

In this paper, a hypsometric analysis script has been used which is developed by the second author and published on ESRI website as a morphometric toolbox working under ArcGIS v.10.x. The analysis was carried out using a developed morphometric toolbox, as shown in Fig. 4. The 
input layers are ASTER GDEM data (Fig. 5) and drainage network (Fig. 6a) to select the subbasins outlets and delineate their watersheds. In the current study, fifteen sub-basins (Fig. 6b) are extracted from ASTER GDEM data using the ArcGIS v. 10.3-hydrology toolbox based on the flow directions; accumulation flows, drainage network and pour points of the outlets. The developed hypsometric analysis toolbox has been used as shown its windows in Fig. 7. DEM data and subbasins boundaries layer are used as inputs to calculate $\mathrm{HC}$ and $\mathrm{HI}$ for Al-Adhaim sub-basins.

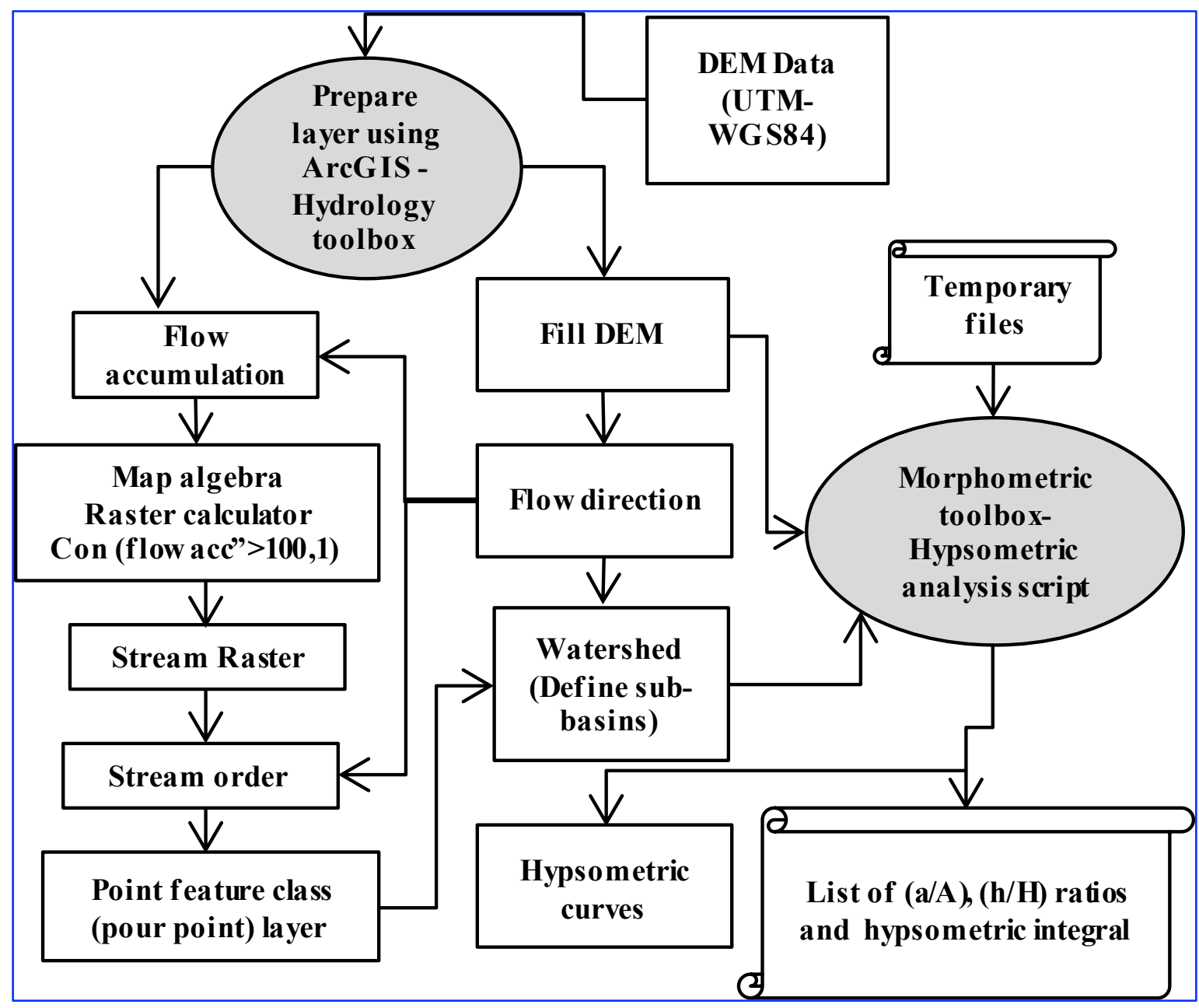

Fig. 4. Steps of the hypsometric analysis script 


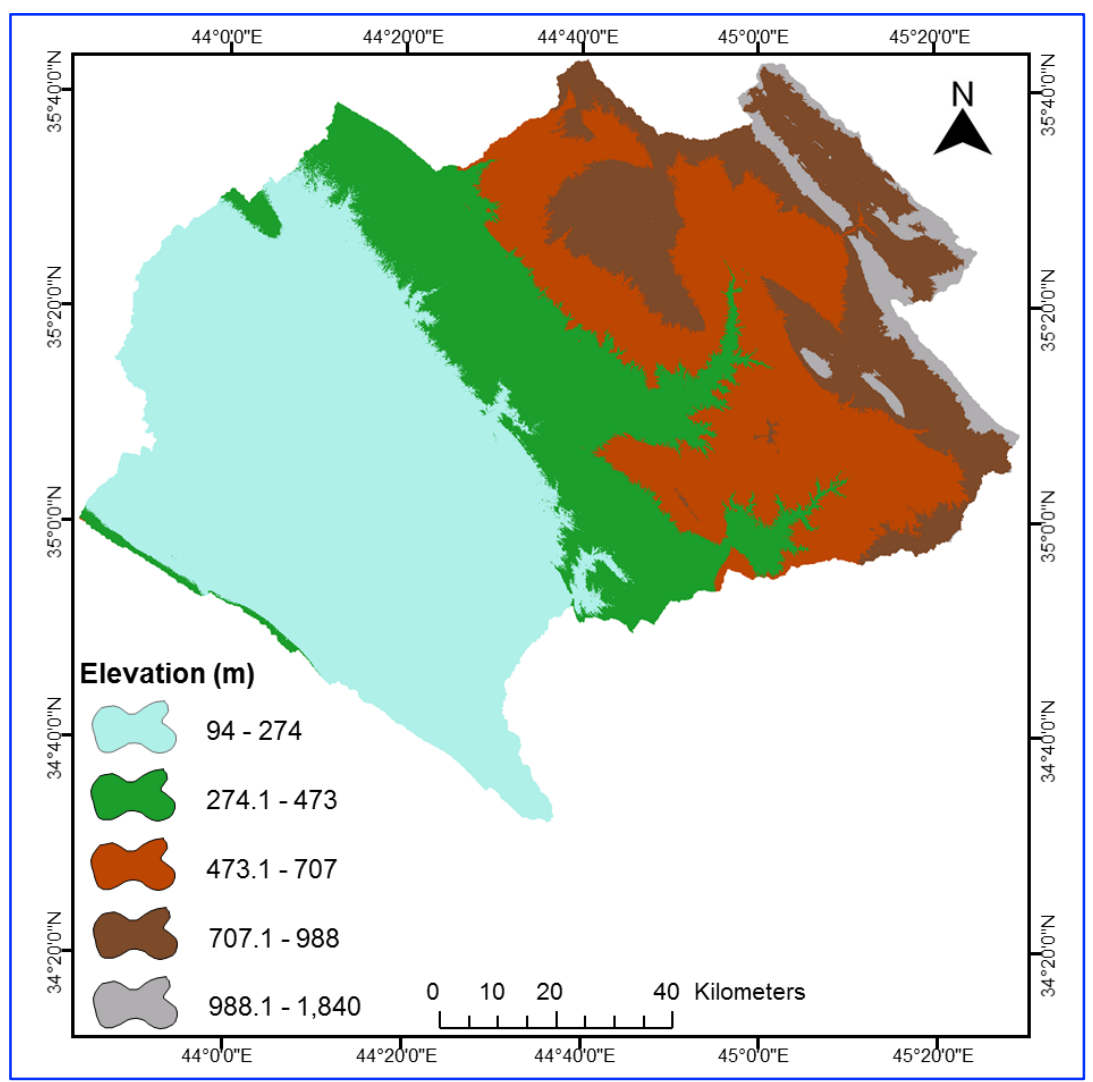

Fig. 5. ASTER- GDEM data

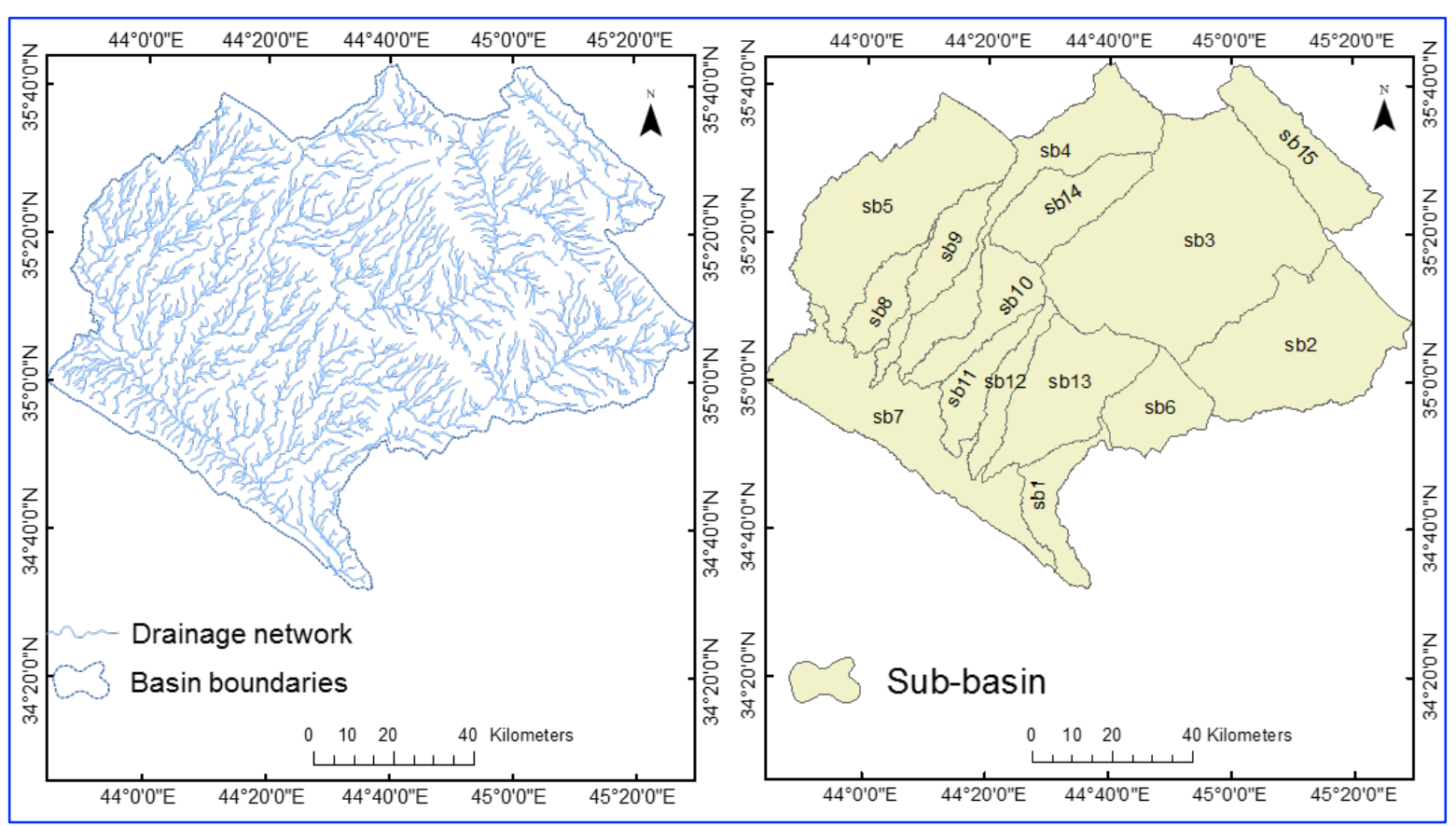

Fig. 6. a. Map of drainage networks b. Map of sub-basins 


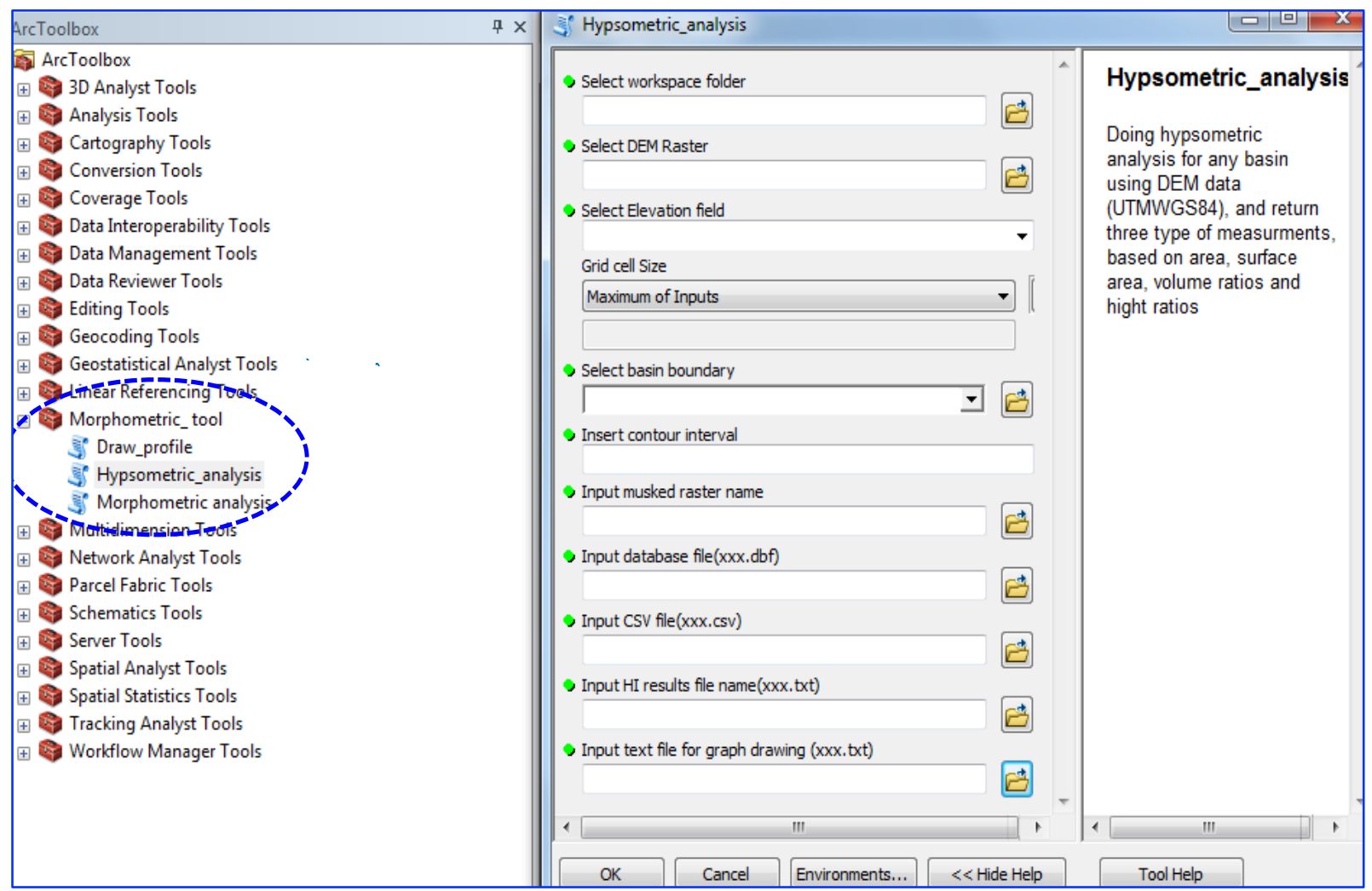

Fig. 7. Window of input layers and files used in the execution of hypsometric analysis script

The hypsometric analysis script is developed and used in this study to calculate the area under the curve (AUC) using the trapezoidal rule, Fig. 8 as follows (Kiusalaas, 2013):

$I=[f(a)+f(b)] \frac{h}{2}$

Where:

$\mathrm{I}=$ Area,

$\mathrm{h}=\Delta \mathrm{x}=\mathrm{b}-\mathrm{a}$, by substitution $\mathrm{f}(\mathrm{x})$ with $\mathrm{f}(\mathrm{h} / \mathrm{H})$

$H I=\left(\sum_{i=1}^{n}\left(\left(\frac{h}{H}\right) i+\left(\frac{h}{H}\right) i+1\right) \times \frac{\left(\frac{a}{A}\right)_{i}-\left(\frac{a}{A}\right)_{i+1}}{2} \times 100\right)$

Where:

$\mathrm{n}=$ number of rows in hypsometric ratios table. 


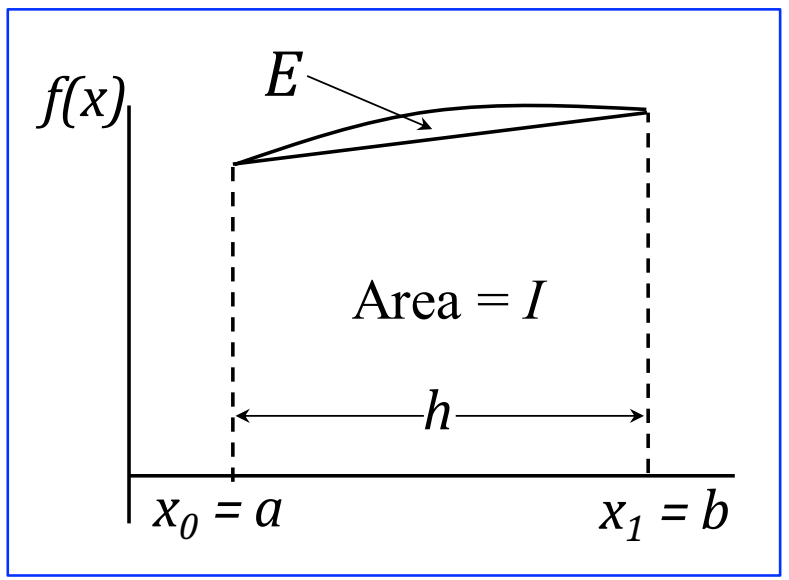

Fig. 8. Trapezoidal rules

\section{Analysis the geomorphic stages by overlying the physical factors}

The area of controlling factors of a geomorphic stage within each sub-basin was identified by the intersection and then followed by summarizing the results table based on sub-basin name by summing the area of each factor within the sub-basin; consequently, the areas are used to calculate the percentage of each factor within each sub-basin.

\section{RESULTS AND DISCUSSION}

The results of the hypsometric analysis of the entire basin are illustrated in area-elevation ratios in Table 1 and the main basin HC in Fig. 9. According to the HI of 19.03\% and concave hypsometric curve, the basin has been passing in Monadnock geomorphic stage and fully stabilized watershed. The results of the spatial analysis of fifteen sub-basins are shown in HCs in Fig. 9 and HIs in Table 2. To focus light on the sub-basins, geomorphic stages and their controlling factor, area percentages of each factor are calculated as listed in Table 2 and illustrated spatially on maps in Fig. 10. From the achieved results; two groups of geomorphic stages are recognized, the first group including most of the sub-basins, sb6, sb15, sb1, sb13, sb3, sb2, sb7 sb12, sb10, and sb5 with HI values between $18.4 \%$ and $34.6 \%$, obviously, the sub-basins are fully stabilized and passing in Monadnock geomorphic stage. The development of these sub-basins was affected mainly by dominant Tertiary age lithology, marl, limestone, gypsum, sandstone, siltstone, and claystone covering percentage between $9.9 \%$ at $\mathrm{Sb} 12$ to $100 \%$ at $\mathrm{Sb} 2$ and $\mathrm{Sb} 6$ with an average of $54.4 \%$.

The sub-basins are located in the zone of moderate and strong to steep slopes, especially at Sb15, covered by $40.5 \%$. Such relatively steep slopes lead to accelerating the weathering and erosion processes. Structurally, sub-basins are located in the folded zone with high lineament 
density ranged from 0.19 to $0.46 \mathrm{~km} / \mathrm{kms}$ with an average of $0.33 \mathrm{~km} / \mathrm{kms}$ and rising of lineament density lead to increasing rock fragmentation and erosion processes. Hydrological soil group-A; recognized by gravelly soil with low runoff are dominant in sub-basins located at the downstream area of the Al-Adhaim dam basin, sb7, sb12, and sb1. In contrast, groups B, C, and D are more dominant in the other sub-basins. The second group of sab-basins includes sb8, sb9, sb11, sb14, and sb4, are passing in equilibrium and later maturity stage with $\mathrm{HI}$ range from $36.4 \%$ to $42.4 \%$, indicating still some rock mass and soil materials are waiting for the weathering and erosion processes. Several factors are controlling the denudation process in these sub-basins including flat to gentle slope covering about 85 to $100 \%$ of the sub-basins area with an average of $92.9 \%$, and these gentle slopes will reduce the erosion and transportation of water during surface runoff and lead to increasing drainage density in the area. The area covered by quaternary deposits of clastic materials and sheet runoff sediments covering 36.4 to $100 \%$ of the sub-basins area with an average of $70.6 \%$ and soil group-D mostly clayey soil with high runoff and low infiltration is more dominant in mature stage sub-basins. HC of sub-basins sb4 and sb14 shows erosion process at the upstream area and deposition at the downstream area. While $\mathrm{HC}$ of the most other sub-basins indicate, the eroded materials are mostly transported out of their catchments.

Table 1. Values of relative height $(\mathrm{h} / \mathrm{H})$, and relative area $(\mathrm{a} / \mathrm{A})$ ratios of Al-Adhaim basin

\begin{tabular}{|c|c|c|c|c|}
\hline $\begin{array}{l}(\mathrm{h} / \mathrm{H}) \\
\text { ratio }\end{array}$ & $\begin{array}{l}(\mathrm{a} / \mathrm{A}) \\
\text { Ratio }\end{array}$ & $\begin{array}{l}(\mathrm{h} / \mathrm{H}) \\
\text { ratio }\end{array}$ & $\begin{array}{l}(\mathrm{a} / \mathrm{A}) \\
\text { Ratio }\end{array}$ & \multirow{18}{*}{$\begin{array}{l}\text { Minimum height }(\mathrm{m})=94.0 ; \\
\text { Maximum height }(\mathrm{m})=1840.0 ; \\
\text { elevation interval }(\mathrm{m})=50 ; \\
\text { Total basin height }(\mathrm{m})=1746.0 ; \\
\text { Total basin area }(\mathrm{Km} 2)=11831.15 ; \\
\text { HI }=19.02(\text { Monadnock stage) }\end{array}$} \\
\hline 0 & 1 & 0.48585 & 0.03969 & \\
\hline 0.02858 & 0.97576 & 0.51443 & 0.02856 & \\
\hline 0.05716 & 0.75391 & 0.54301 & 0.02116 & \\
\hline 0.08574 & 0.62299 & 0.57159 & 0.01539 & \\
\hline 0.11432 & 0.5491 & 0.60017 & 0.01123 & \\
\hline 0.1429 & 0.48077 & 0.62875 & 0.0086 & \\
\hline 0.17148 & 0.44408 & 0.65733 & 0.00649 & \\
\hline 0.20006 & 0.40971 & 0.68591 & 0.0048 & \\
\hline 0.22864 & 0.36882 & 0.71449 & 0.00348 & \\
\hline 0.25722 & 0.32336 & 0.74307 & 0.00251 & \\
\hline 0.2858 & 0.27383 & 0.77165 & 0.00186 & \\
\hline 0.31438 & 0.22669 & 0.80023 & 0.00137 & \\
\hline 0.34296 & 0.18325 & 0.82881 & 0.00096 & \\
\hline 0.37154 & 0.14557 & 0.85739 & 0.00061 & \\
\hline 0.40012 & 0.11633 & 0.88597 & 0.00028 & \\
\hline 0.4287 & 0.08819 & 0.91455 & 0.00008 & \\
\hline 0.45728 & 0.05906 & 0.94313 & 0.00002 & \\
\hline
\end{tabular}



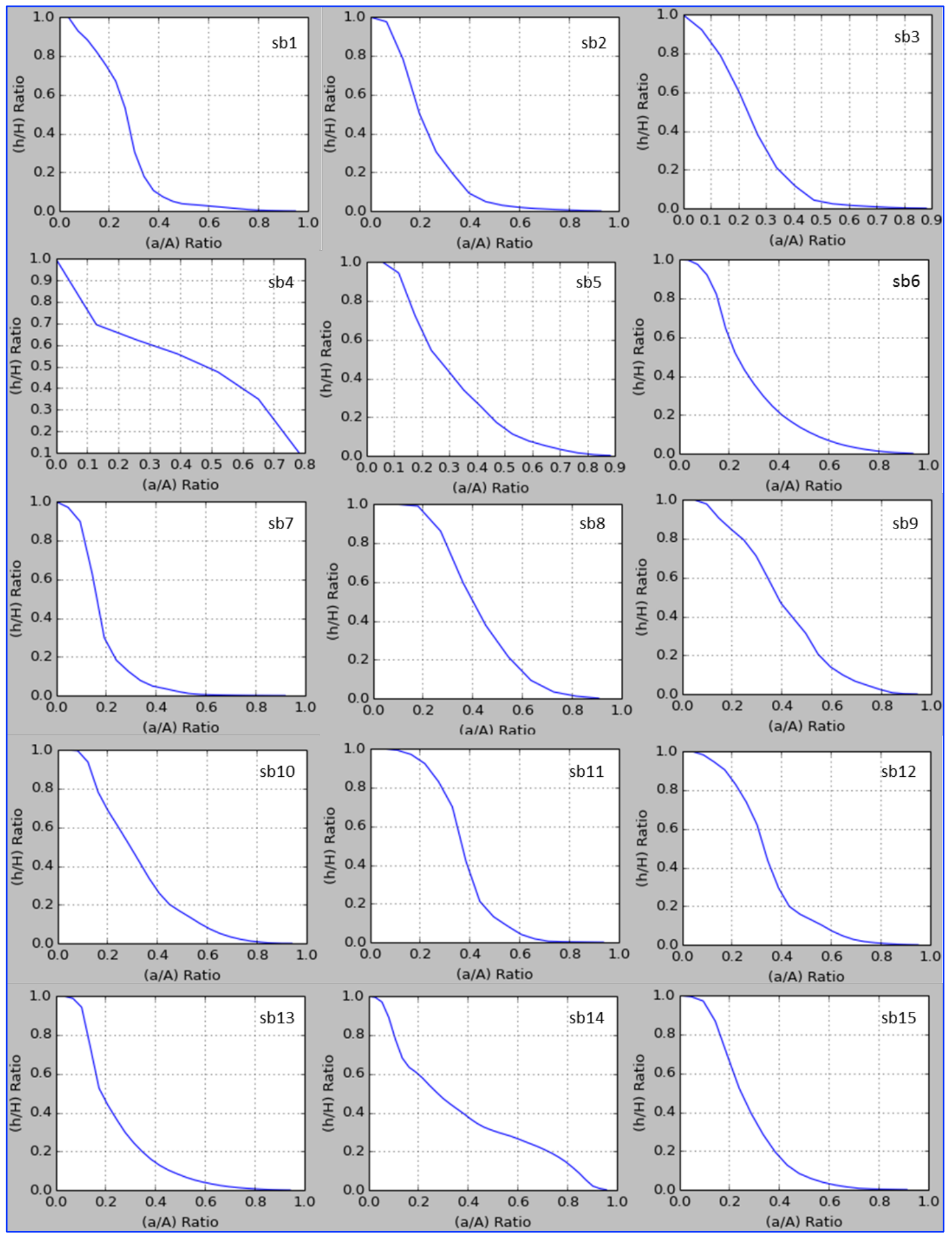

Fig. 9. HC for sub-basins 
Table 2. HI, geomorphic stages and controlling factors of the sub-basins

\begin{tabular}{|c|c|c|c|c|c|c|c|c|c|c|c|c|c|}
\hline \multirow[b]{2}{*}{ 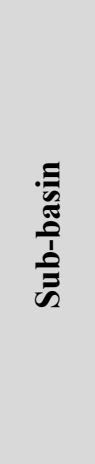 } & \multirow[b]{2}{*}{ 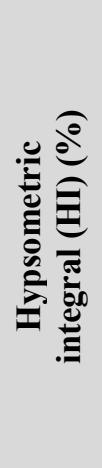 } & \multicolumn{3}{|c|}{ Terrain slopes (\%) } & \multicolumn{2}{|c|}{$\begin{array}{l}\text { Geologic } \\
\text { outcrops } \\
\text { Age (\%) }\end{array}$} & \multirow{2}{*}{ 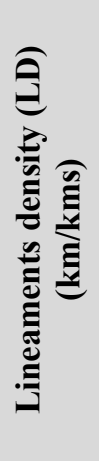 } & \multirow{2}{*}{ 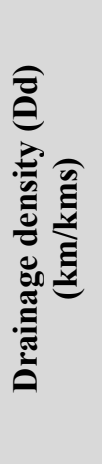 } & \multicolumn{4}{|c|}{ Hydrologic Soil group (\%) } & \multirow[b]{2}{*}{ 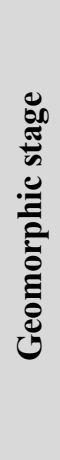 } \\
\hline & & 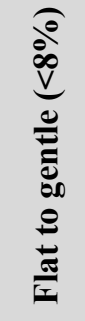 & 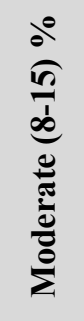 & 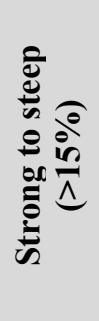 & & 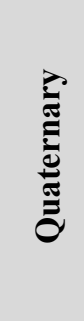 & & & $\mathbf{A}$ & B & C & D & \\
\hline Sb7 & 18.4 & 96.3 & 3.2 & 0.6 & 22.7 & 77.3 & 0.19 & 0.56 & 1.8 & 43.7 & 31.3 & 23.1 & \multirow{10}{*}{ 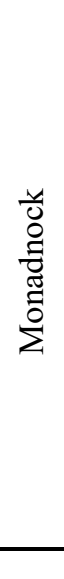 } \\
\hline Sb2 & 23 & 60.3 & 27.5 & 12.3 & 100 & 0 & 0.35 & 0.5 & 0 & 67 & 8.9 & 24.1 & \\
\hline Sb3 & 24.2 & 67 & 22.5 & 10.6 & 96.7 & 3.3 & 0.41 & 0.53 & 0 & 79.1 & 2 & 18.9 & \\
\hline Sb13 & 24.3 & 76.4 & 23.2 & 0.4 & 49.6 & 50.4 & 0.36 & 0.56 & 0 & 10.6 & 18.3 & 71.1 & \\
\hline Sb1 & 26.5 & 97.1 & 2.4 & 0.5 & 46.4 & 53.6 & 0.45 & 0.53 & 23.6 & 15.8 & 37.4 & 23.3 & \\
\hline Sb15 & 27.8 & 36 & 23.6 & 40.5 & 74.4 & 25.7 & 0.35 & 0.4 & 0 & 0.1 & 99.9 & 0 & \\
\hline Sb6 & 28.7 & 86.8 & 10.6 & 2.7 & 100 & 0 & 0.46 & 0.51 & 0 & 19 & 0 & 81 & \\
\hline Sb5 & 30.7 & 99.4 & 0.6 & 0 & 22.1 & 77.9 & 0.23 & 0.6 & 0 & 13.7 & 5.3 & 81 & \\
\hline Sb10 & 32.1 & 99.6 & 0.4 & 0 & 22.1 & 77.9 & 0.26 & 0.58 & 0 & 4.4 & 9.5 & 86.1 & \\
\hline Sb12 & 34.6 & 97.8 & 2.1 & 0.1 & 9.7 & 90.3 & 0.27 & 0.54 & 15.4 & 3.6 & 45.5 & 35.5 & \\
\hline Avg. & 27.03 & 81.7 & 11.6 & 6.8 & 54.4 & 45.6 & 0.33 & 0.53 & 4.1 & 25.7 & 25.8 & 44.4 & \\
\hline Sb4 & 36.4 & 84.9 & 13.1 & 2 & 63.6 & 36.4 & 0.22 & 0.52 & 0 & 61 & 1.5 & 37.5 & \multirow{5}{*}{$\begin{array}{l}\stackrel{\mathscr{E}}{E} \\
\text { 莺 }\end{array}$} \\
\hline Sb14 & 37.1 & 80.2 & 17.1 & 2.7 & 82.6 & 17.4 & 0.39 & 0.54 & 0 & 79.1 & 0 & 20.9 & \\
\hline Sb11 & 37.7 & 99.7 & 0.3 & 0 & 0.9 & 99.1 & 0.14 & 0.51 & 3 & 0 & 33.6 & 63.4 & \\
\hline Sb9 & 40.1 & 100 & 0 & 0 & 0 & 100 & 0.28 & 0.57 & 0 & 0 & 13.4 & 86.6 & \\
\hline Sb8 & 42.4 & 100 & 0 & 0 & 0 & 100 & 0.27 & 0.59 & 0 & 0 & 19 & 81 & \\
\hline Avg. & 38.7 & 92.9 & 6.1 & 0.9 & 29.4 & 70.6 & 0.3 & 0.54 & 0.6 & 28.02 & 13.5 & 57.9 & \\
\hline
\end{tabular}

Previous studies have mentioned that the morphometric characteristics of the studied area are based on traditional calculation methods and GIS techniques. A study was carried out on two subbasins of Adhaim river basin, Tuz Chi and Sheikh Muhsin (Quri) sub-basins calculated the HI of the two sub-basins as $87 \%$ and $67 \%$, respectively which means both are youth with slight tendency to mature in Sheikh Muhsin (Quri) sub-basin (Al Izzi, 2005) and another study was carried out on the morphometric characteristics of the basin and the effect of rainfall storm on the surface runoff and discharge of Adhaim river was calculated the HI of Al- Adhaim basin as youth basin with HI about 91.1\% (Saloom, 2009). All the previous studies are not able to describe the erosion conditions and geomorphologic development stages in different parts of the Adhaim River basin. This 
variation in the calculation of $\mathrm{HI}$ is due to human errors and a problem in the calculating area under the curve (AUC).

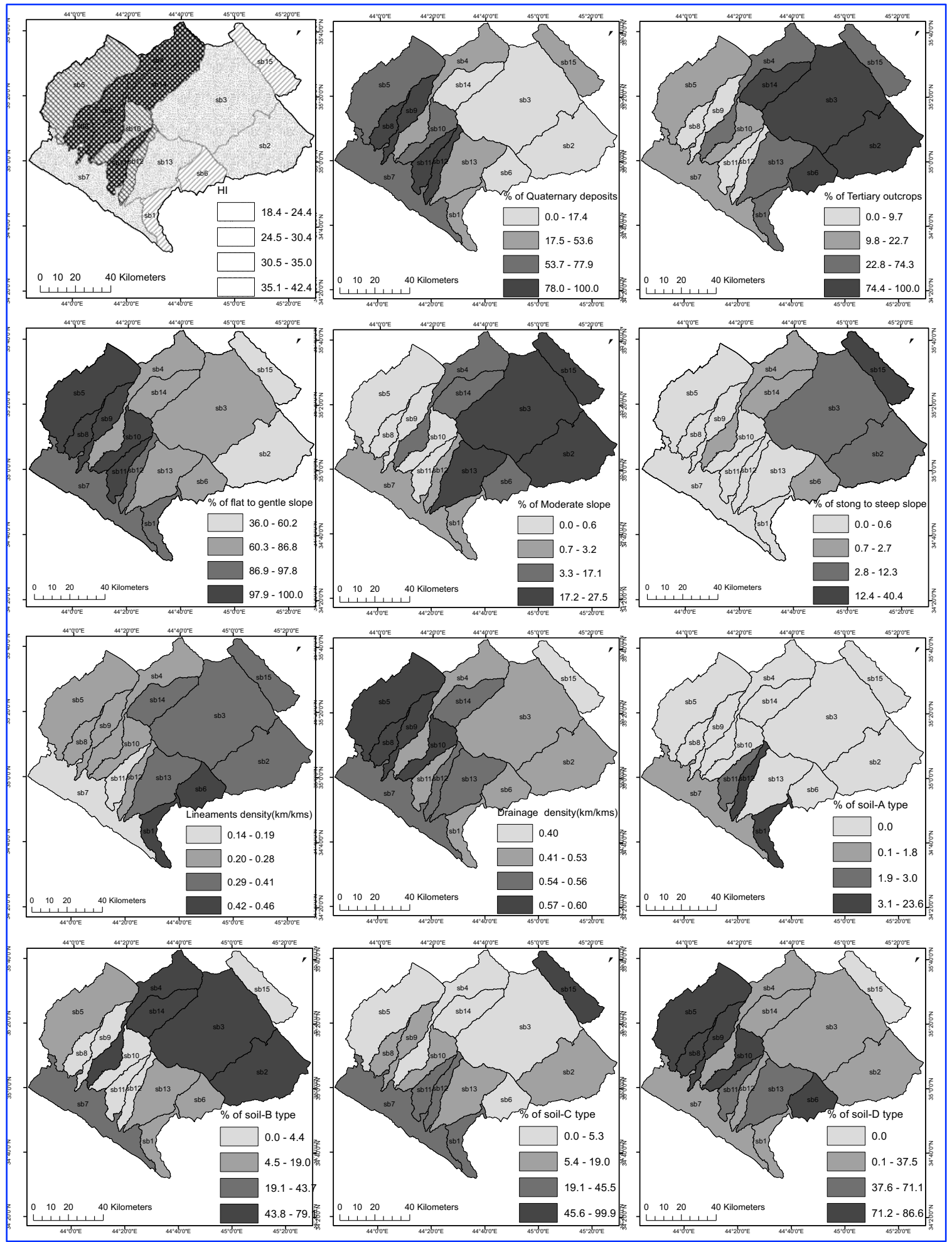

Fig. 10. Percentage distribution of essential controlling factors of sub basins 


\section{CONCLUSIONS}

The most important conclusions based on developed hypsometric analysis GIS technique as the followings:

1- Al-Adhaim basin has been passing through Monadnock geomorphic stage with $\mathrm{HI}$ equal to $19.02 \%$.

2- $\mathrm{HC}$ and $\mathrm{HI}$ results for sub-basins of Al-Adhaim basin are reached Monadnock geomorphic stage, and few of them are passing through the mature phase.

3- From intersected maps, sub-basins with Monadnock geomorphic stage show strong spatial relations with a high percentage of Tertiary formations area, high density of lineaments, high percentage of moderate slope and relatively high of steep slope, high percentage area of groupB of hydrological soil (Coarse soil).

4- From intersected maps, sub-basins with mature geomorphic stage show strong spatial relations with high percentage of Quaternary deposits area, low density of lineaments, high percentage of flat and gentle, high percentage area of group-D of hydrological soil (Fine soil), and related to high density which could due to sheet runoff because of flat and gentle slope.

5- In fact, the developed hypsometric analysis script of morphometric toolbox was proved as an efficient analysis GIS tool for facilitating the comparative analysis of sub-basins by exposing all the analyzed sub-basins to the same calculation measures and keeping the same accuracy degree of the results. The lithology, structure, slopes, and soil are the main factors controlling the denudation processes and development stages of Al-Adhaim dam sub-basins.

\section{ACKNOWLEDGMENTS}

The authors are very grateful to the Editor in Chief Prof. Dr. Salih M. Awadh, the Secretary of Journal Mr. Samir R. Hijab and the Technical Editor Dr. Heba S. Al-Mimar for their great efforts and valuable comments.

\section{REFERENCES}

Abbas, N., Wasimi, S., Al-Ansari, N., and Nasrin Baby, S., 2018. Recent trends and long-range forecasts of water resources of Northeast Iraq and climate change adaptation measures. Journal of Water, 10(11): 1562.

Ahmed, F., and Rao, S., 2016. Hypsometric analysis of the Tuirini drainage basin: A Geographic Information System approach. International Journal of Geomatics and Geosciences, 6(3): 1685-1695.

Al-Kubaisi, Q.Y., Hussain, T.A. and Rasheed, A.A., 2018. Hydraulic properties of the Bai-hassan aquifer in TuzKhurmatu, Salahaddin, Iraq. The Iraqi Geological Journal: 113-129.

Al Izzi, A. M., 2005. The Geomorphologic Evaluation and the Mechanism Changes for the Structures of Both Tuz Chi and Sheikh Muhsin Beds Basin of Udhaim River, Baghdad, unpublished, 211 pp. 
Beg, A. A. F., 2008. Hypsometric Analyst Extension- ArcView GIS v3.x. ESRI, available at: http://arcscripts.esri.com/details.asp?dbid=15934.

Buday, T., 1980. The Regional Geology of Iraq: Stratigraphy and Paleogeography, vol. 1. Dar Al-Kutub, Mosul, 445.

Buday, T., and Jassim, S., 1987. The Regional geology of Iraq, Vol. 2: Tectonism, Magmatism and Metamorphism. GEOSURV, Baghdad, Iraq, 352 pp.

Buringh, P., 1960. Soils and Soil Conditions in Iraq. Ministry of agriculture Baghdad.

Cohen, S., Willgoose, G., and Hancock, G., 2008. A methodology for calculating the spatial distribution of the areaslope equation and the hypsometric integral within a catchment. Journal of Geophysical Research, 113(F3).

Davis, J., 2010. Hypsometry toolbox -ArcGIS v. 9.3. ESRI, Environmental Systems Research Institute (ESRI) website.

Dowling, T .I., Walker, J., Richardson, D. P., O'Sullivan, A., and Summerell, G. K., 1998. Application of the Hypsometric Integral and other Terrain Based Metrics as Indicators of Catchment Health: A Preliminary Analysis. CSIRO, Land and Water.

Gökgöz, T., Yayla, Y., Yaman, M. ,B., Güvenç, H. and Kaya, S., 2016. Developing tools for computation of basin topographic parameters in GIS. isprs - International Archives of the Photogrammetry, Remote Sensing and Spatial Information Sciences, XLII-2/W1: 165-168.

Hurtrez, J. E., Sol, C., and Lucazeau, F., 1999. Effect of drainage area on hypsometry from an analysis of small-scale drainage basins in the Siwalik Hills (Central Nepal). Earth Surface Processes and Landforms, 24(9): 799-808.

Jassim, S. Z. and Goff, J. C., 2006. Geology of Iraq Dolin, Prague and Moravian Museum, Brno, Czech Republic, 439 pp.

Khatun, S. and Pal, S., 2016. Analysis of regional hypsometric integral to identify landscape evolution in Kushkarani River Basin. JGEESI, 6(3): 1-17.

Kiusalaas, J., 2013. Numerical Methods in Engineering with Python 3. Cambridge university press.

Langbein, W.B., 1947. Topographic Characteristics of Drainage Basins. US Government Printing Office USA.

Marouf, N. Z., and Al-Kubaisi, M. S. A., 2005. Inversion and folding of the southern un-elevated folded belt in North Iraq. The Iraqi Geological Journal: 1-36.

Miller, V. C., 1953. A Quantitative Geomorphic Study of Drainage Basin Characteristics in the Clinch Mountain area Virginia and Tennessee. Department of Geology, University of Colombia.

Moglen, G. E., and Bras, R. L., 1995. The effect of spatial heterogeneities on geomorphic expression in a model of basin evolution. Water Resources Research, 31(10): 2613-2623.

Muhaimeed, A. S., Saloom, A., Saliem, K., Alani, K., and Muklef, W., 2014. Classification and distribution of Iraqi soils. International Journal of Agriculture Innovations and Research, 2(6): 997-1002.

Ohmori, H., 1993. Changes in the hypsometric curve through mountain building resulting from concurrent tectonics and denudation. Geomorphology, 8(4): 263-277.

Patel, P.P., and Sarkar, A., 2010. Terrain characterization using SRTM data. Journal of the Indian Society of Remote Sensing, 38(1): 11-24.

Rashid, A. A., Al-Dabbas, M. A., and Kadhim, W. H., 2016. Assessment of groundwater quality for drinking in Tuz Khurmatu area, Salahadden Governorate, Iraq. the Iraqi Geological Journal, 91-103.

Saloom, F. H., 2009. Characteristics of Storm Rainfall and its Impact on River Discharge in the Al-Udhaim Basin For the period (1975 - 2005), Baghdad, unpublished.

Schumm, S. A., 1956. Evolution of drainage systems and slopes in badlands at perth amboy, new jersey. Geological Society of America Bulletin, 67(5): 597.

Singh, O., Sarangi, A., and Sharma, M. C., 2008. Hypsometric integral estimation methods and its relevance on erosion status of North-Western Lesser Himalayan Watersheds. Water Resource, 22(11): 1545-1560.

Sissakian, V. K., 1993. Geological Map of Kirkuk Quadrangles. In: Geosurv (Editor), geology maps. unpublished, Iraq. Baghdad.

Sivakumar, V., Biju, C., and Deshmukh, B., 2011. Hypsometric analysis of Varattaru river basin of Harur taluk, Dharmapuri districts, Tamilnadu, India using geomatics technology. International Journal of Geomatics and Geosciences, 2(1): 241-247. 
Soares, P. C., and Riffel, S. B., 2006. Hypsometric curves as a tool for paleosurface mapping. Mathematics Geology, 38(6): 679-695.

Sreedevi, P. D., Owais, S., Khan, H. H., and Ahmed, S., 2009. Morphometric analysis of a watershed of South India using SRTM data and GIS. Journal of the Geological Society of India, 73(4): 543-552.

Strahler, A. N., 1952a. Hypsometric (area-altitude) analysis of erosional topography. Geological Society of America Bulletin, 63(11): 1117-1142.

Strahler, A. N., 1952b. Hypsometric (area-altitude) analysis of erosional topography. Geological Society of America Bulletin, 63(11): 1117.

Strahler, A. N., 1957. Quantitative analysis of watershed geomorphology. Transactions, American Geophysical Union, 38(6): 913.

USGS, 2016. Landsat 8 (OLI,TIRS) image. https://earthexplorer.usgs.gov/ ; access date :26/07/2016, USA.

Vanderwaal, J. A., and Ssegane, H., 2013. Do polynomials adequately describe the hypsometry of Monadnock phase watersheds? JAWRA Journal of the American Water Resources Association, 49(6): 1485-1495.

Vivoni, E. R., Di Benedetto, F., Grimaldi, S., and Eltahir, E. A., 2008. Hypsometric control on surface and subsurface runoff. Water Resource, 44(12).

Willgoose, G., and Hancock, G., 1998. Revisiting the hypsometric curve as an indicator of form and process in transport-limited catchment. Earth Surface Process. Landf., 23(7): 611-623.

Zavoianu, I., 1985. Morphometry of drainage basins. Elsevier. 